\title{
ASSESSMENT OF NATURAL RADIOACTIVITY LEVEL IN SHORE SEDIMENT SAMPLES From NASSER LAKE AT ASWAN, EGYPT
}

\author{
A. Abu Taleb, Abbady A, Harb S \\ Physics department, Faculty of Science, South Valley University. Egypt
}

\begin{abstract}
Thirty shore sediment samples taken from the side beach of Lake Nasser in south Arab Republic of Egypt to measuring the terrestrial radionuclides radium-226, thorium-232 and potassium-40 and its associated hazard indices. The activity concentration of natural radionuclides ${ }^{226} \mathrm{Ra},{ }^{232} \mathrm{Th}$ and $40_{k}$ in shore sediments samples under investigation are ranged from $1.92 \pm 0.077$ to $17.55 \pm 0.676 \mathrm{Bqkg}^{-1}$ with average value of $5.02 \pm 0.194 \mathrm{Bqkg}^{-1}, 5.62 \pm 0.281$ to $28.77 \pm 1.441 \mathrm{Bqkg}^{-1}$ with average value of $13.15 \pm 0.641 \mathrm{Bqkg}^{-1}$ and $123.27 \pm 10.604$ to $277.38 \pm 23.861 \mathrm{Bqkg}^{-1}$ with average value of $200.26 \pm 17.054 \mathrm{Bqkg}^{-1}$ respectively .The radiation hazard indices which resulting from the presence of natural radionuclides in shore sediment samples were calculated and the obtained results indicate that the values of radium equivalent activity varies from 21.85 to $80.04 \mathrm{~Bq} / \mathrm{kg}$ with average value of $39.25 \mathrm{~Bq} / \mathrm{kg}$, representative level index Irr varies from 0.16 to 0.58 with average value of 0.29.Absorbed dose rate varies from 10.63 to $37.541 \mathrm{nGy} \cdot \mathrm{h}^{-1}$ with the average value of $18.83 n G y \cdot h^{-1}$. External hazard index Hix varies from 0.059 to 0.216 with average value of 0.105, internal hazard index Hin varies from 0.070 to 0.263 with average value of 0.119, annual outdoor effective dose varied from 0.013 to $0.046 \mathrm{mSvy}^{-1}$ with average values $0.023 \mathrm{mSvy}^{-1}$ andThe indoor effective dose ranged from 0.052 to $0.184 \mathrm{mSvy}^{-1}$, with average values $0.092 \mathrm{mSvy}^{-1}$.
\end{abstract}

\section{KEYWORDS}

Activity concentration, NaI (TI), Nasser Lake, Radiation hazards, Shore Sediments

\section{INTRODUCTION}

There are a lot of sources of radiation in the environment. The activity concentration levels of terrestrial radioactive nuclides which found in air, sediments, water ,building materials and other component of the environment are depending on the properties of the geological, geochemical and geographical of the region under studied and appear at different rates of the world $[1,2,3,4]$. Gamma- ray released from naturally occurring radionuclides, always called terrestrial background radiation, it is responsible for the main external source of exposure to the human body. Human beings are exposed to radiation fundamentally from cosmic radiation and from the gamma ray released in soils, building materials, water, food, and air. Natural radionuclides have basically existed in the environment since the creation of the universe. Nuclides with half-lives equal to the age of the ground or their identical disintegration products like ${ }^{40} \mathrm{~K}$, and the radioactive nuclides which resulting from the decay of the ${ }^{238} \mathrm{U}$ and ${ }^{232} \mathrm{Th}$ series can still be found on earth[5].In our world all people are insecure due to the exposure ofradiation released from natural radioactive materials which found in earth's crust and also from man-made sources [6].Based on that, it is indispensable to survey the levels of terrestrial radionuclides in the various components of the environment to obtain the achievement of comprehensive surveys in any nation. Naturally occurring radionuclides of terrestrial origin are existing in rivers and lakes sediments [7]. 
Sediment plays a role in piling and transferring contaminants within the geographic region and is considered the environmental host of the waste discharged by natural or man-made processes in our universe. Lakes doing as basin for the materials which pass through the different aquatic chemical and biological circles including radionuclide contaminants. The assessment of natural radioactivity levels in Nasser Lake are gives benefits to continue the program of measuring natural radioactivity in different environmental media in south Egypt started in the Environmental Radioactivity Measurements Laboratory, physics department, Faculty of Science, South Valley University, Qena, Egypt since 1990.[8-12].

\subsection{Stay Area}

In the 1960's.,a high dam was built on the Nile river at Aswan in Egypt during this time, the water flooded an area in the Nile Valley behind dam estimated at $6,200 \mathrm{~m}^{2}$ making one of the big manmade lakes in the world (fig. 1) which changed the Egyptian environment[13,14].. This lake was named Lake Nasser and located at the border between Egypt and Sudan between latitudes 21.8 to $24.0^{\circ} \mathrm{N}$ and Longitudes 31.3 to $33.1^{\circ} \mathrm{E}$. The largest surface area and maximum storage capacity of the reservoir are estimated at 600 and $162 \mathrm{~km} 3$, respectively [15].Nasser Lake is underlain and surrounded by a wide variety of rocks that include granitoids, gneisses, schists in its southern parts and Nubian sandstones and tertiary and quaternary basalts in the north.

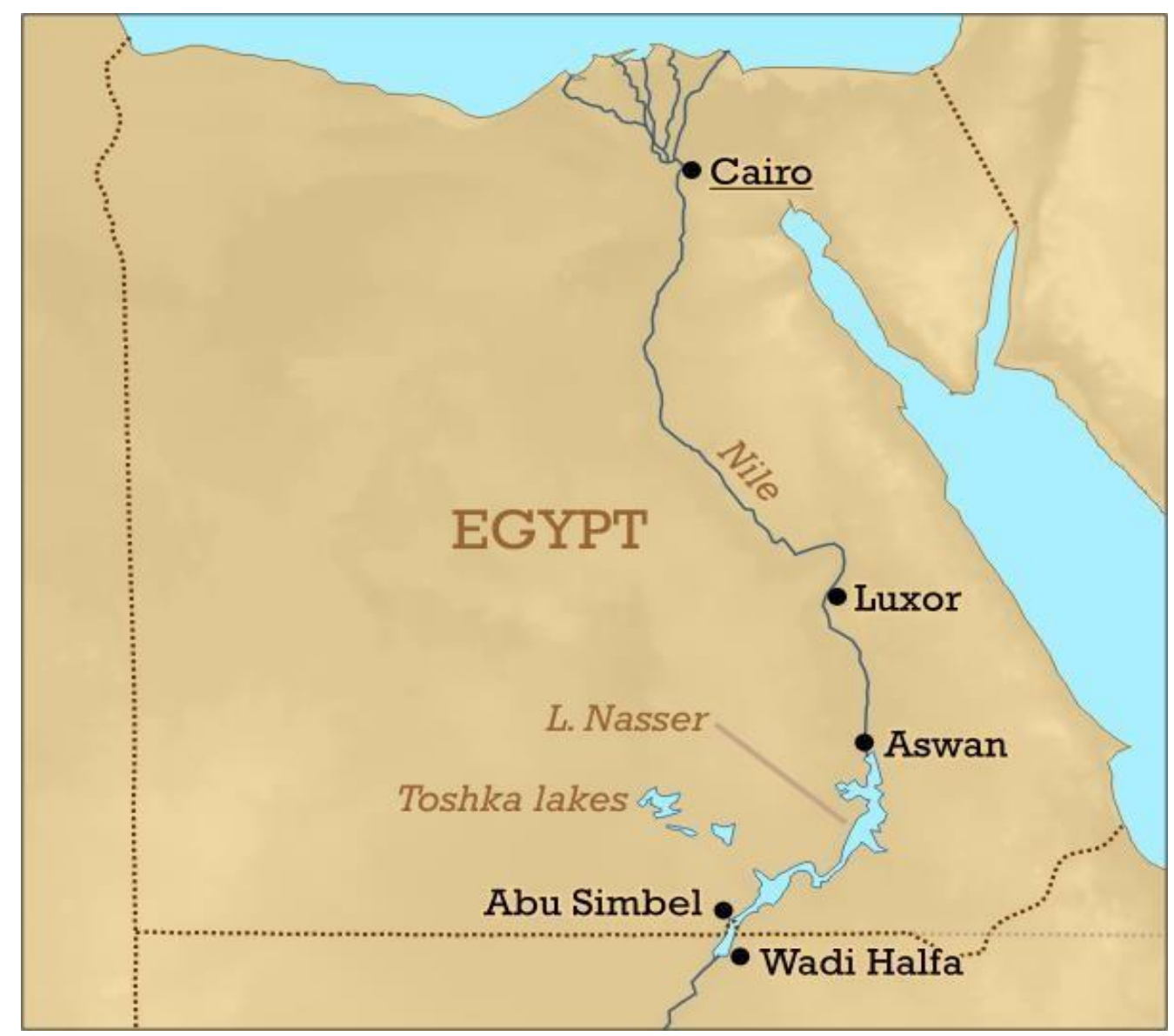

Figure 1. Nasser Lake 


\section{Material And Methods}

\subsection{Sample Collection And Preparation}

Thirty shore sediment samples taken from the side beach at depth of about $0.5-1 \mathrm{~m}$ of Lake Nasser in south Egypt to measuring the terrestrial radionuclides ${ }^{226} \mathrm{Ra},{ }^{232} \mathrm{Th}$ and ${ }^{40} \mathrm{~K}$. Data from Global Positioning System (GPS) will used for tracking the data record in order to obtain a representative sample (Table 1). The masses of the collected samples varied between 0.75 to 1

$\mathrm{kgm}$.. The samples were then drying at $100^{\circ} \mathrm{C}$ to ensure that moisture is completely removed. The samples were stored in tight containers for 30 days before starting the counting by using gamma spectrometry in order to ensure that the daughter products of ${ }^{226} \mathrm{Ra}$ up to ${ }^{210} \mathrm{~Pb}$ and of ${ }^{228} \mathrm{Th}$ up to ${ }^{208} \mathrm{~Pb}$ achieve equilibrium with their respective parent radionuclides [16].

\subsection{Experimental Setup}

To calculate the average concentration of naturally occurring radioactivity in the present study we measured the concentration of ${ }^{226} \mathrm{Ra},{ }^{232} \mathrm{Th}$ and ${ }^{40} \mathrm{~K}$ in shore sediment samples by using gamma- ray spectrometer consisting of a NaI (TI) setup and multichannel analyzer 8192 channel, with the following conditions: resolution (FWHM) at $1.33 \mathrm{MeV}{ }^{60} \mathrm{Co}$ is $60 \mathrm{keV}$, relative efficiency at $1.33 \mathrm{MeV}{ }^{60} \mathrm{Co}$ is $7.5 \%$. In order to maintain the detector and reduce the effect of the background radiation, it must be placed in a middle of wall double chamber. The first wall is made of stainless steel with $10 \mathrm{~mm}$ thick and the other wall is made of lead with $30 \mathrm{~mm}$ thick. After preparation of the samples it was placed above the detector for at least $10 \mathrm{~h}$. To analyse the spectrum we use computer software program Maestro (EG\&G ORTEC). Activity concentration of ${ }^{226} \mathrm{Ra}$ in shore sediment samples was analyzed the counts at gamma energies of 295.22 , $351.93 \mathrm{keV}$ and $609.31,1120,1764.49 \mathrm{keV}$, emitted from daughter nuclides ${ }^{214} \mathrm{~Pb}{ }^{214} \mathrm{Bi}$ respectively. ${ }^{232} \mathrm{Th}$ activity of the sample was determined from the Girondist nuclides $\left({ }^{228} \mathrm{Ac}\right)$, $\left({ }^{212} \mathrm{~Pb}\right)$ and $\left({ }^{208} \mathrm{Ti}\right)$ through the intensity of $209.25,338.32,911.2 \mathrm{keV}$ Gamma-lines for $\left({ }^{228} \mathrm{Ac}\right),\left({ }^{212} \mathrm{~Pb}\right)$ emissions at $238.63 \mathrm{keV}$ and $\left({ }^{208} \mathrm{Ti}\right)$ emissions at 583.19, $2614 \mathrm{keV}$ Gammalines. ${ }^{40} \mathrm{~K}$ activity determined from the $1460.7 \mathrm{keV}$ emissions Gamma-lines.

\subsection{Radioactivity Measurements}

Activity concentrations of natural radionuclides in shore sediment samples were calculated by using the following formula $[17,18]$.

$\mathrm{Ca}$

$\mathrm{AS}=\longrightarrow \mathrm{Bq} / \mathrm{kg}$

$\eta \operatorname{Pr} \mathrm{Ms}$

Where Ca is the net counting of $\gamma$-ray (counts per second), $\eta$ the detector efficiency of specific $\gamma$ ray, Pr the absolute transition probability of $\gamma$-decay and Ms the mass of the sample in $\mathrm{kg}$.

\section{RADIATION HAZARD INDICES}

The best indicator for radiation hazard is called radium equivalent activity Raeq [19,20], which is a weighted sum of activities of the three natural radionuclides based on the estimation that 370 $\mathrm{Bq} / \mathrm{kg}$ of ${ }^{226} \mathrm{Ra}, 259 \mathrm{~Bq} / \mathrm{kg}$ of ${ }^{232} \mathrm{Th}$ and $4810 \mathrm{~Bq} / \mathrm{kg}$ of ${ }^{40} \mathrm{~K}$ produce the same gamma-ray dose rate[21,22]. Raeq was calculated from the next equation [20]. 
Raeq (Bq.Kg-1 ) $=\mathrm{ARa}+1.43 \mathrm{ATh}+0.077 \mathrm{AK}$

Where ARa, ATh, and AK, are the activity concentrations of ${ }^{226} \mathrm{Ra},{ }^{232} \mathrm{Th}$ and ${ }^{40} \mathrm{~K}$ respectively. To estimate the level of $\gamma$-radiation hazard associated with the natural radionuclides in specific investigated samples, Representative Level Index were used which calculated from the following relation $[23,24]$.

$\mathrm{I} \gamma \mathrm{r}=(1 / 150) \mathrm{ARa}+(1 / 100) \mathrm{ATh}+(1 / 1500) \mathrm{AK}$

Absorbed dose (D) assess the energy which stored in a medium due to the ionizing radiation emitted from natural occurring radionuclides and measured in SI units as joules per kilogram (Gray Gy).It is calculated based on guide lines provided by UNSCEAR 2000. D can be calculated according to [25]:

$\mathrm{D}(\mathrm{nGy} \cdot \mathrm{h}-1)=0.462 \mathrm{ARa}+0.621 \mathrm{ATh}+0.0417 \mathrm{AK}$

External and internal hazard indices which resulting from exposure to radon and its daughters are calculated from the following equations respectively [20,17]:

$\mathrm{Hex}=(\mathrm{ARa} / 370+\mathrm{ATh} / 259+\mathrm{AK} / 4810) \leq 1$

Hin $=(\mathrm{ARa} / 185+\mathrm{ATh} / 259+\mathrm{AK} / 4810) \leq 1$

The annual indoor and outdoor effective dose rate in $\mathrm{mSv} / \mathrm{yr}$ is given by the following formulas respectively. [25]

Indoor effective dose rate $\left(\mathrm{m} \mathrm{Svy}^{-1}\right)=\mathrm{D}\left(\mathrm{nGy} \mathrm{h}^{-1}\right) \times 8760 \mathrm{~h} \times 0.8 \times 0.7 \mathrm{SvGy}^{-1} \times 10^{-6}$

Outdoor Effective dose rate $\left(\mathrm{m} \mathrm{Svy}^{-1}\right)=\mathrm{D}\left(\mathrm{nGy} \mathrm{h}^{-1}\right) \times 8760 \mathrm{~h} \times 0.2 \times 0.7 \mathrm{SvGy}-1 \times 10^{-6}(8)$

\section{RESUlts AND Discussions}

The activity concentration in $(\mathrm{Bq} / \mathrm{kg})$ of ${ }^{226} \mathrm{Ra},{ }^{232} \mathrm{Th}$ and ${ }^{40} \mathrm{~K}$ for shore sediment samples collected from Nasser Lake are listed in (Table1) and shown in figure (2).From the results, activity concentration varies from $1.92 \pm 0.077$ to $17.55 \pm 0.676$ with average value of $5.02 \pm 0.194$, from 5.62 \pm 0.281 to $28.77 \pm 1.441$ with average value of $13.15 \pm 0.641$ and from $123.27 \pm 10.604$ to $277.38 \pm 23.861$ in with average value of $200.26 \pm 17.054$ in $(\mathrm{Bq} / \mathrm{kg})$ for ${ }^{226} \mathrm{Ra},{ }^{232} \mathrm{Th}$ and ${ }^{40} \mathrm{~K}$ respectively .The averages values of activity concentration are smaller than the universal average given by UNSCEAR (2000), which due to Most of sediments in Nasser Lake are silts and sands derived from basic intermediate volcanic rocks that are representative of the provenances of Ethiopia and Sudan with minor contribution from the underlying and surrounding rocks [26]. Table 2and figure 3 indicates that the obtained results in this study are lower than the results in similar studies when compared to each other. The obtained values of the radiation hazard indices of shore sediment samples are listed in table 3 and shown in (figures 4,5and 6). Results indicate that, radium equivalent activities Raeq ranged from 21.85 to $80.04 \mathrm{~Bq} / \mathrm{kg}$ with average value of $39.25 \mathrm{~Bq} / \mathrm{kg}$; this value is less than the internationally accepted value $370 \mathrm{~Bq} / \mathrm{Kg}$ [27].Representative level index I $\gamma \mathrm{r}$ ranging from 0.17 to 0.59 with an average value of 0.30.The $(\mathrm{I} \gamma)$ values of all samples are within the world standard value [27].. Absorbed dose rate $\mathrm{D}\left(\mathrm{nGyh}^{-}\right.$ 1) ranged from 10.63 to $37.54\left(\mathrm{nGyh}^{-1}\right)$ with an average value of $18.38 \mathrm{nGyh}^{-1}$ and less than the estimate of average global terrestrial radiation of $55\left(\mathrm{nGyh}^{-1}\right)$ [27]. Indoor and outdoor annual effective dose rate from these samples are ranged from 0.052 to $0.184 \mathrm{mSvy}^{-1}$ with an average value of $0.092 \mathrm{mSvy}^{-1}$ and from 0.013 to $0.046 \mathrm{mSvy}^{-1}$ with an average value of $0.023 \mathrm{mSvy}^{-1}$ 
respectively and all values are less than the recommended limit of $1 \mathrm{mSv} / \mathrm{y}$, UNSCEAR, 2000 while The external and internal hazard indices are varies from 0.059 to 0.216 with average value of 0.106 and from 0.071 to 0.264 with average value of 0.120 respectively. The average estimated values of Hex and Hin which calculated in this work were minimum than unity [28], which are appropriate with the universal values

\section{Conclusions}

The activity concentrations of ${ }^{226} \mathrm{Ra},{ }^{232} \mathrm{Th}$, and ${ }^{40} \mathrm{~K}$ in the studied samples are found to be normal and below the average global values. The average values of radium equivalent activity Raeq, gamma dose rate D, Indoor and outdoor annual effective dose rate, External hazard index and internal hazard index Hex and $\mathrm{Hi}$ and representative level index I $\gamma \mathrm{r}$ were all found to be lower than the worldwide average values. By reference to the values of radiation hazard indices for all shore sediments samples collected from Lake Nasser, shore sediment can be used safely in agriculture, construction and also do not be a radioactive danger to the people which live beside the lake.

Table.1: Activity concentration of ${ }^{226} \mathrm{Ra},{ }^{232} \mathrm{Th}$ and ${ }^{40} \mathrm{~K}$ in shore sediment samples

\begin{tabular}{|c|c|c|c|c|c|}
\hline \multirow{2}{*}{$\begin{array}{l}\text { Sample } \\
\text { code }\end{array}$} & \multicolumn{2}{|l|}{ Coordinates } & \multicolumn{3}{|c|}{ Activity concentration $(\mathrm{Bq} / \mathrm{Kg})$} \\
\hline & Latitude(N) & Longitude (E) & Ra-226 & Th-232 & $\mathrm{K}-40$ \\
\hline S1 & $23^{\circ} 58^{\prime} 152^{\prime \prime}$ & $32^{\circ} 51^{\prime} 950^{\prime \prime}$ & $4.14 \pm 0.160$ & $10.58 \pm 0.527$ & $186.71 \pm 16.062$ \\
\hline $\mathrm{S} 2$ & $23^{\circ} 58^{\prime} 45^{\prime \prime}$ & $32^{\circ} 51^{\prime} 866^{\prime \prime}$ & $4.24 \pm 0.164$ & $14.76 \pm 0.733$ & $255.59 \pm 21.986$ \\
\hline S3 & $23^{\circ} 57^{\prime} 837^{\prime \prime}$ & $32^{\circ} 51^{\prime} 832^{\prime \prime}$ & $5.00 \pm 0.196$ & $23.47 \pm 1.170$ & $247.812 \pm 21.317$ \\
\hline S4 & $23^{\circ} 56^{\prime} 4$ & & $10.99=$ & $23.94 \pm 1.911$ & $257.01 \pm 22.109$ \\
\hline S5 & $23^{\circ} 56^{\prime} 52^{\prime \prime}$ & $32^{\circ} 50^{\prime} 775^{\prime \prime}$ & $17.55 \pm 0.676$ & $28.77 \pm 1.441$ & $277.38 \pm 23.861$ \\
\hline S6 & $23^{\circ} 56^{\prime} 212^{\prime \prime}$ & $32^{\circ} 50^{\prime} 491^{\prime \prime}$ & $7.57 \pm 0.283$ & $16.77 \pm 0.835$ & $215.87 \pm 18.570$ \\
\hline S7 & $23^{\circ} 56^{\prime} 85^{\prime \prime}$ & $181^{\prime \prime}$ & $4.83 \pm 0.186$ & $9.76 \pm 0.494$ & $240.1 \pm 17.479$ \\
\hline S8 & $23^{\circ} 5$ & & $6.89 \pm($ & 12. & 61 \\
\hline S9 & $23^{\circ} 5$ & & 4.45 & $17.67 \pm 0$ & 38 \\
\hline S10 & $23^{\circ} 54^{\prime} 5$ & & 7.02 & $11.83 \pm 0$ & $268.41 \pm 2$ \\
\hline S11 & $23^{\circ} 54^{\prime} 68$ & & $5.04 \pm 0$ & $9.70 \pm 0$. & $245.59 \pm 2$ \\
\hline S12 & $23^{\circ} 54^{\prime} 790^{\prime \prime}$ & $2^{\prime \prime}$ & $6.14 \pm 0.241$ & $12.93 \pm 0.648$ & $178.39 \pm 15.346$ \\
\hline S13 & $23^{\circ} 55^{\prime} 5$ & & $4.28 \pm 0.167$ & 17. & $197.4 \pm 1$ \\
\hline S14 & $23^{\circ} 58^{\prime} 1$ & & 0.102 & $15.88 \pm$ & $161.15 \pm 13.862$ \\
\hline S15 & $22^{\circ} 20^{\prime} 653^{\prime \prime}$ & $1^{\prime \prime}$ & $2.46 \pm 0.095$ & $14.59 \pm 0.736$ & $194.53 \pm 16.734$ \\
\hline S16 & $22^{\circ} 20^{\prime} 6$ & & $2.49 \pm 0.097$ & $9.99 \pm 0.499$ & $167.65 \pm 14.422$ \\
\hline S17 & $22^{\circ} 20^{\prime} 543$ & $6^{\prime} 714^{\prime \prime}$ & $2.45 \pm 0.095$ & $10.71 \pm 0$ & $131.73 \pm 11.332$ \\
\hline S18 & $22^{\circ} 20^{\prime} 44^{\prime}$ & $36^{\prime} 686^{\prime \prime}$ & $4.33 \pm 0.168$ & $5.62 \pm 0.281$ & $123.27 \pm 10.606$ \\
\hline S19 & $22^{\circ} 20^{\prime} 3$ & $698^{\prime \prime}$ & $4.42 \pm 0.175$ & $6.34 \pm 0$. & $185.09 \pm 15.922$ \\
\hline S20 & $22^{\circ} 20^{\prime} 166^{\prime \prime}$ & $6^{\prime \prime}$ & $4.82 \pm 0$ & $9.79 \pm$ & $218.29 \pm 18.778$ \\
\hline S21 & $22^{\circ} 19^{\prime} 935^{\prime \prime}$ & $37^{\prime} 326^{\prime \prime}$ & $1.92 \pm 0.077$ & $8.23 \pm 0.411$ & $184.03 \pm 15.831$ \\
\hline S22 & $22^{\circ} 19^{\prime} 891^{\prime \prime}$ & $31^{\circ} 37^{\prime} 408^{\prime \prime}$ & $3.59 \pm 0.143$ & $12.5 \pm 0.627$ & $199.42 \pm 17.155$ \\
\hline S23 & $22^{\circ} 20^{\prime} 103$ & & $4.09 \pm 0.160$ & $17.53 \pm 0.873$ & $195.05 \pm 16.779$ \\
\hline $\mathrm{S} 24$ & $22^{\circ} 20^{\prime} 113^{\prime \prime}$ & $31^{\circ} 36^{\prime} 829^{\prime \prime}$ & $4.58 \pm 0.183$ & $10.37 \pm 0.535$ & $193.39 \pm 16.636$ \\
\hline S25 & $22^{\circ} 20^{\prime} 133^{\prime \prime}$ & & $4.14 \pm 0.165$ & $8.94 \pm 0.454$ & $184.5 \pm 15.871$ \\
\hline S26 & $22^{\circ} 20^{\prime} 141^{\prime \prime}$ & $31^{\circ} 36^{\prime} 779^{\prime \prime}$ & $4.45 \pm 0.153$ & $11.62 \pm 0.489$ & $153.59 \pm 11.182$ \\
\hline S27 & $22^{\circ} 20^{\prime} 145^{\prime \prime}$ & $31^{\circ} 36^{\prime} 727^{\prime \prime}$ & $2.43 \pm 0.095$ & $7.49 \pm 0.372$ & $148.61 \pm 12.784$ \\
\hline S28 & $22^{\circ} 20^{\prime} 112^{\prime \prime}$ & $31^{\circ} 36^{\prime} 796^{\prime \prime}$ & $5.45 \pm 0.212$ & $14.21 \pm 0.724$ & $174.9 \pm 15.045$ \\
\hline
\end{tabular}


International Journal of Biomedical Engineering and Science (IJBES), Vol. 6, No. 1, January 2019

\begin{tabular}{|l|l|l|l|l|}
\hline S29 $22^{\circ} 20^{\prime} 115^{\prime \prime}$ & $31^{\circ} 36^{\prime} 687^{\prime \prime}$ & $4.28 \pm 0.165$ & $8.57 \pm 0.440$ & $178.27 \pm 15.335$ \\
\hline S30 $22^{\circ} 20^{\prime} 507^{\prime \prime}$ & $31^{\circ} 36^{\prime} 589^{\prime \prime}$ & $3.95 \pm 0.156$ & $12.44 \pm 0.659$ & $190.93 \pm 16.424$ \\
\hline Minimum & & $1.92 \pm 0.077$ & $5.62 \pm 0.281$ & $123.27 \pm 10.604$ \\
\hline Maximum & $17.55 \pm 0.676$ & $28.77 \pm 1.441$ & $277.38 \pm 23.861$ \\
\hline Average & $5.02 \pm 0.194$ & $13.15 \pm 0.641$ & $200.26 \pm 17.054$ \\
\hline
\end{tabular}

Table 2: Comparison of Radiological parameters of present work with other studies

\begin{tabular}{|l|c|c|c|l|}
\hline Location & ${ }^{226} \mathrm{Ra}$ & $232 \mathrm{Th}$ & ${ }^{40} \mathrm{~K}$ & References \\
\hline present (work) & $5.02 \pm 0.194$ & $13.15 \pm 0.641$ & $\begin{array}{l}200.26 \pm \\
17.054\end{array}$ & Present work \\
\hline Buruls Lake) & 14.3 & 20 & 312 & {$[29]$} \\
\hline Mariout Lake & $12.65 \pm 1.53$ & $7.24 \pm 0.76$ & $518.75 \pm 46.24$ & {$[30]$} \\
\hline Suez Canal & $10.69 \pm 0.25$ & $13.71 \pm 0.28$ & $194.58 \pm 0.81$ & {$[31]$} \\
\hline Qarun Lake & $23.5 \pm 9.7$ & $14.1 \pm 6.2$ & $933 \pm 384$ & {$[32]$} \\
\hline Idku Lake & 20.37 & 26.05 & 329.18 & {$[33]$} \\
\hline Worldwide & 32 & 45 & 420 & {$[25]$} \\
\hline
\end{tabular}

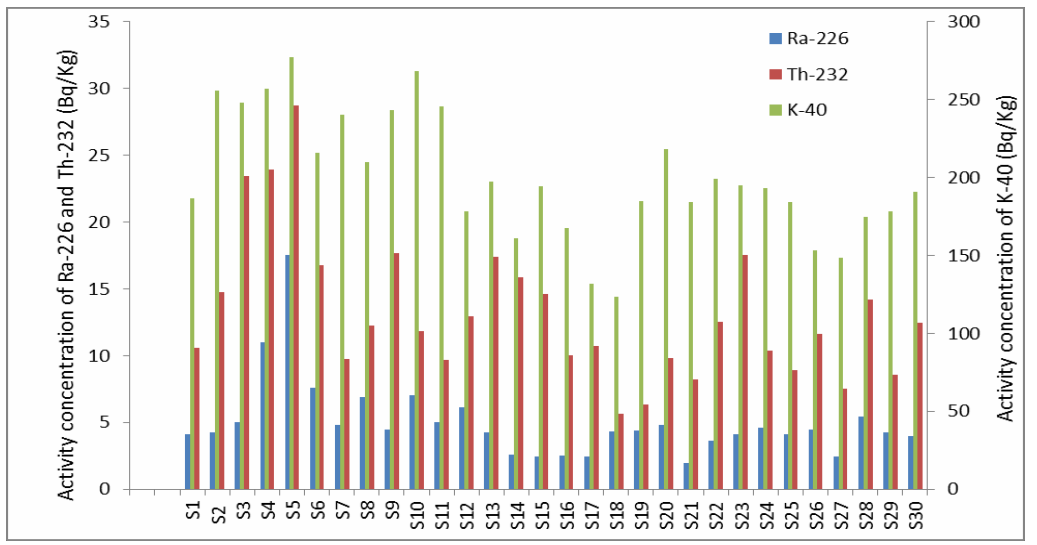

Figure $2 .{ }^{226} \mathrm{Ra},{ }^{232} \mathrm{Th}$ and ${ }^{40} \mathrm{~K}$ activity concentrations in shore sediment samples

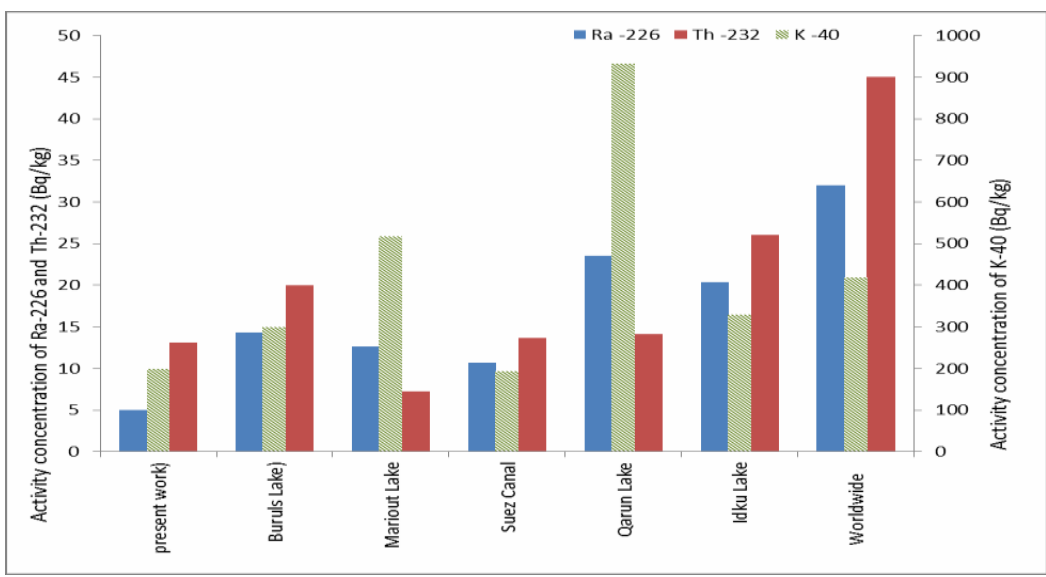

Figure 3. Comparison of ${ }^{226} \mathrm{Ra},{ }^{232} \mathrm{Th}$ and ${ }^{40} \mathrm{~K}$ activity concentrations in samples of present work with other studies 
International Journal of Biomedical Engineering and Science (IJBES), Vol. 6, No. 1, January 2019

Table 3. radiation hazard indices of shore sediment samples.

\begin{tabular}{|c|c|c|c|c|c|c|c|}
\hline Sample & $\begin{array}{l}\text { Raeq } \\
\left(\mathrm{Bq} \cdot \mathrm{Kg}^{-1}\right)\end{array}$ & $\mathrm{I}_{\mathrm{v}_{\mathrm{r}}}$ & $\begin{array}{c}\mathrm{D} \\
\left(\mathrm{nGyh}^{-1}\right)\end{array}$ & $\begin{array}{l}\text { Indoor effective } \\
\text { dose }\left(\mathrm{msvy}^{-1}\right)\end{array}$ & $\begin{array}{l}\text { Outdoor effective } \\
\text { dose }\left(\mathrm{msvy}^{-1}\right)\end{array}$ & Hin & Hex \\
\hline S1 & 33.65 & 0.26 & 16.27 & 0.080 & 0.020 & 0.102 & 0.091 \\
\hline S2 & 45.03 & 0.35 & 21.78 & 0.107 & 0.027 & 0.133 & 0.122 \\
\hline S3 & 57.64 & 0.43 & 27.22 & 0.134 & 0.033 & 0.169 & 0.156 \\
\hline S4 & 65.01 & 0.48 & 30.66 & 0.150 & 0.038 & 0.205 & 0.176 \\
\hline S5 & 80.05 & 0.59 & 37.54 & 0.184 & 0.046 & 0.264 & 0.216 \\
\hline S6 & 48.17 & 0.36 & 22.91 & 0.112 & 0.028 & 0.151 & 0.130 \\
\hline S7 & 37.27 & 0.29 & 18.30 & 0.090 & 0.022 & 0.114 & 0.101 \\
\hline S8 & 40.59 & 0.31 & 19.55 & 0.096 & 0.024 & 0.128 & 0.110 \\
\hline S9 & 48.46 & 0.37 & 23.18 & 0.114 & 0.028 & 0.143 & 0.131 \\
\hline S10 & 44.60 & 0.34 & 21.78 & 0.107 & 0.027 & 0.139 & 0.120 \\
\hline S11 & 37.82 & 0.29 & 18.59 & 0.091 & 0.023 & 0.116 & 0.102 \\
\hline S12 & 38.37 & 0.29 & 18.31 & 0.090 & 0.022 & 0.120 & 0.104 \\
\hline S13 & 44.36 & 0.33 & 21.01 & 0.103 & 0.026 & 0.131 & 0.120 \\
\hline S14 & 37.73 & 0.28 & 17.79 & 0.087 & 0.022 & 0.109 & 0.102 \\
\hline S15 & 38.30 & 0.29 & 18.31 & 0.090 & 0.022 & 0.110 & 0.103 \\
\hline S16 & 29.68 & 0.23 & 14.35 & 0.070 & 0.018 & 0.087 & 0.080 \\
\hline S17 & 27.91 & 0.21 & 13.28 & 0.065 & 0.016 & 0.082 & 0.075 \\
\hline S18 & 21.86 & 0.17 & 10.63 & 0.052 & 0.013 & 0.071 & 0.059 \\
\hline S19 & 27.74 & 0.22 & 13.70 & 0.067 & 0.017 & 0.087 & 0.075 \\
\hline S20 & 35.63 & 0.28 & 17.41 & 0.085 & 0.021 & 0.109 & 0.096 \\
\hline S21 & 27.86 & 0.22 & 13.67 & 0.067 & 0.017 & 0.080 & 0.075 \\
\hline S22 & 36.82 & 0.28 & 17.74 & 0.087 & 0.022 & 0.109 & 0.099 \\
\hline S23 & 44.18 & 0.33 & 20.91 & 0.103 & 0.026 & 0.130 & 0.119 \\
\hline S24 & 34.30 & 0.26 & 16.62 & 0.082 & 0.020 & 0.105 & 0.093 \\
\hline S25 & 31.13 & 0.24 & 15.16 & 0.074 & 0.019 & 0.095 & 0.084 \\
\hline S26 & 32.89 & 0.25 & 15.68 & 0.077 & 0.019 & 0.101 & 0.089 \\
\hline S27 & 24.58 & 0.19 & 11.97 & 0.059 & 0.015 & 0.073 & 0.066 \\
\hline S28 & 39.24 & 0.30 & 18.64 & 0.091 & 0.023 & 0.121 & 0.106 \\
\hline S29 & 30.26 & 0.23 & 14.73 & 0.072 & 0.018 & 0.093 & 0.082 \\
\hline S30 & 36.44 & 0.28 & 17.51 & 0.086 & 0.021 & 0.109 & 0.098 \\
\hline Min. & 21.85 & 0.17 & 10.63 & 0.052 & 0.013 & 0.071 & 0.059 \\
\hline Max. & 80.04 & 0.59 & 37.54 & 0.184 & 0.046 & 0.264 & 0.216 \\
\hline Average & 39.25 & 0.30 & 18.38 & 0.092 & 0.023 & 0.120 & 0.106 \\
\hline
\end{tabular}


International Journal of Biomedical Engineering and Science (IJBES), Vol. 6, No. 1, January 2019

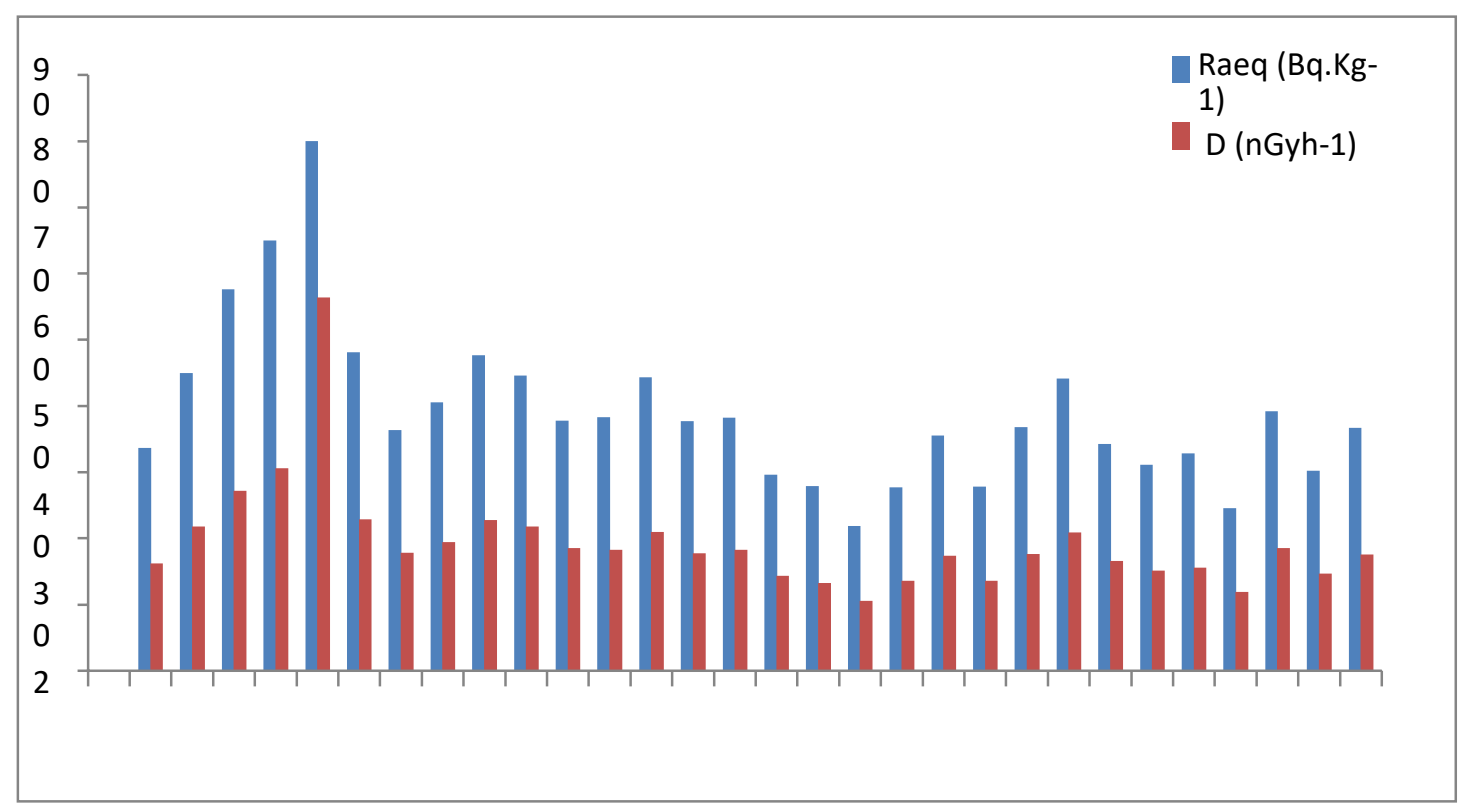

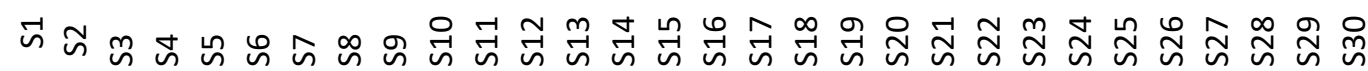

Figure.4: Radium equivalent and absorbed dose rate for all samples under investigation

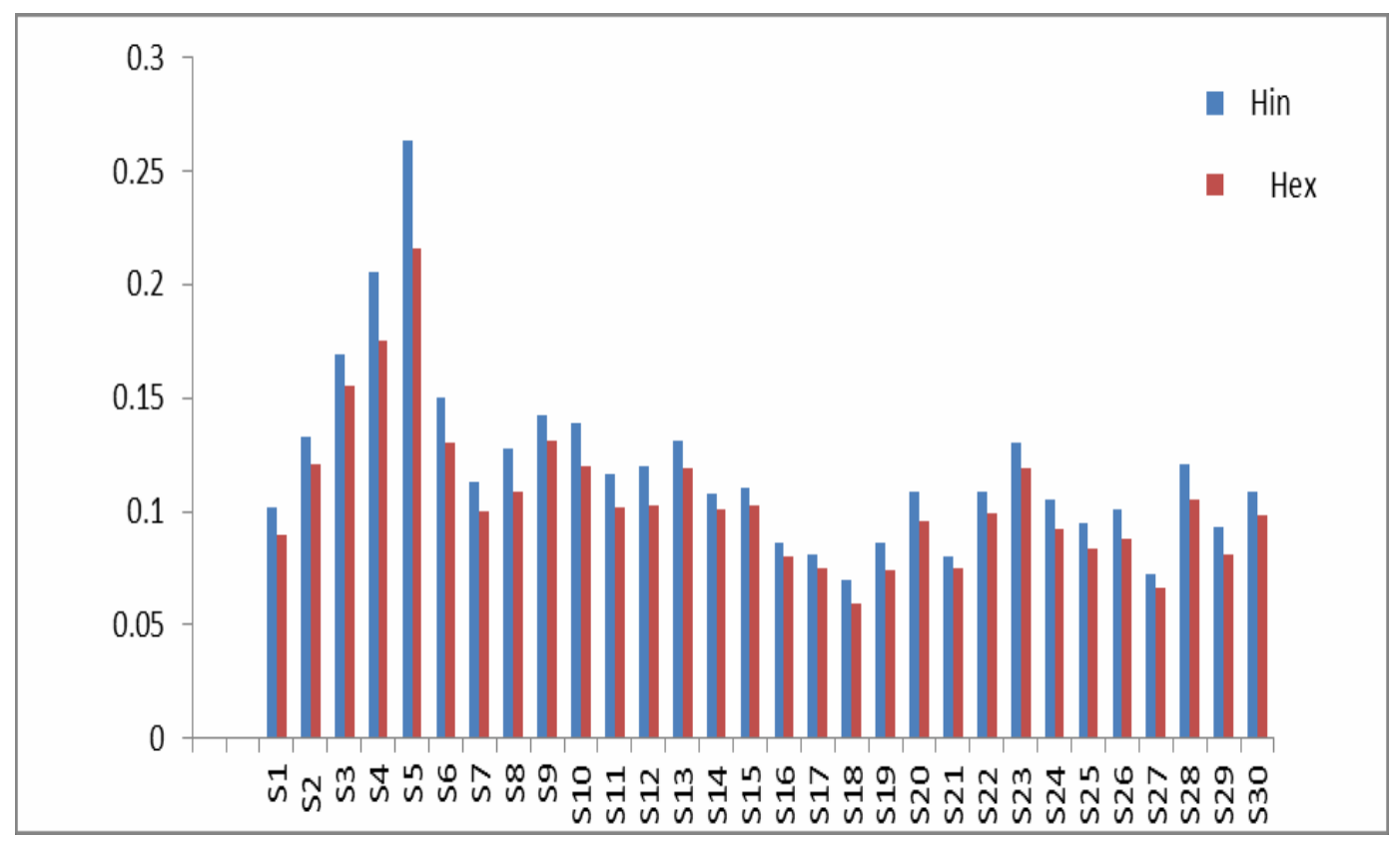

Figure.5: Representative level index, indoor and outdoor effective dose rate of shore sediment samples 


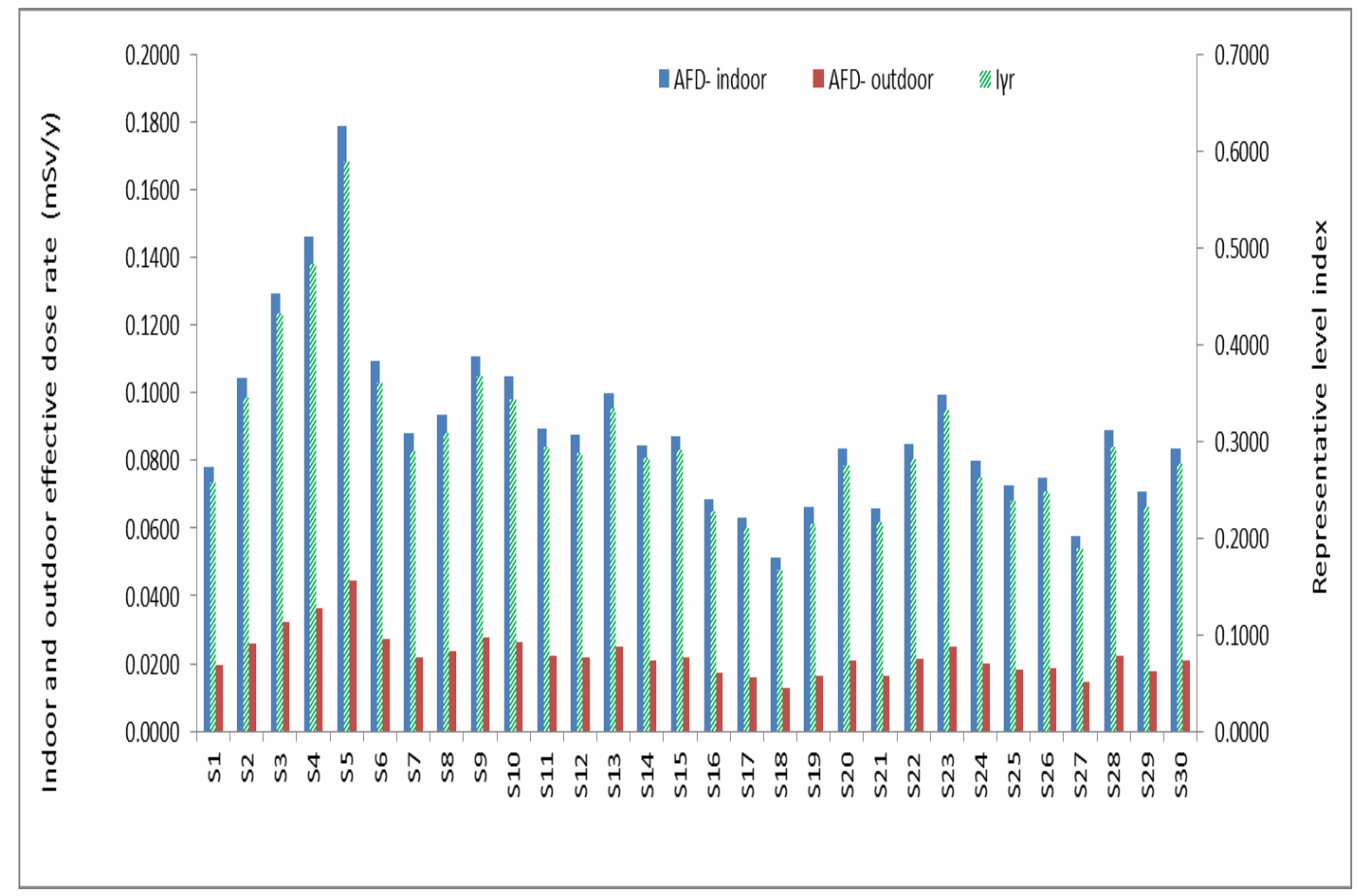

Figure. 6: Internal $\left(\mathrm{H}_{i n}\right)$ and external $\left(\mathrm{H}_{\mathrm{ex}}\right)$ hazard indices of shore sediment samples

\section{REFERENCES}

[1] Iqbal, M., Tufail, M. and Mirza, S.M.,(2000) "Measurement of Natural Radioactivity in Marble Found In Pakistan Using a NaI(Tl) Gamma-Ray Spectrometer”. Technical Note, Journal of Environmental Radioactivity, 51(2), 255-265.

[2] Anagnostakis, M.J., Hinis, E.P., Simopoulos, S.E. and Angelopoulos, M.G,(1996) "Natural Radioactivity Mapping of Greek Surface Soils". Environmental International, 22 (1), 3-8.

[3] Shender, M.A.,(1997) "Measurement of Natural Radioactivity Levels in Soil in Tripoli". Applied Radiation and Isotopes, 48 (1),147-148.

[4] Bathan, K., Mehra, R., Sonkawade, R. G., Singh, S. (2009)“Use of Gamma-Ray Spectrometry for Assessment of Natural Radioactive Dose in Some Sample of Building Materials”, Asian Journal of Chemistry, Vol. 21, No. 10, PP. 207-21

[5] O. Abu Haija,(2012) "Determination of Natural Radionuclides Concentrations in Surface Soil in Tafila/Jordan”, Modern Applied Science, Vol. 6, No. 3.

[6] Tabassum Nasirm, Huda Al-Sulaiti and Patrick Henry Regan,(2012) "Assessment of Radioactivity in Some Soil Samples of Quatar by Gamma-Ray Spectroscopy and the Derived Dose Rates”, Pak. J. sci. ind.res.Ser.A:phys.sci.55(3)128-134.

[7] Krmar M, Slivka J, Varga E, Bikit I, Veskovic M (2009). "Correlations of natural radionuclides in sediment from Danube”. J. Geochem. Explor. 100(1):20-24

[8] Abbady A., Ahmed N. K., Saied M. H., El-Kamel, A. H. and Harb S.,(1995) "Variation of 222Rn concentration in drinking water in Qena", Bull. FAC. SCI,24 (1-A), 101-106. 
International Journal of Biomedical Engineering and Science (IJBES), Vol. 6, No. 1, January 2019

[9] Ahmed N. K., Abbady A., Saied M. H., El-Kamel A. H., and Harb S,(1995) "222Rn concentration of some ground water samples in Upper Egypt”, Bull. FAC. SCI., 24 (1-A), 89-96,

[10]El- Arabi A. M,(2001) "Prediction of the expected inhalation doses by measuring the natural radioactivity of building materials used in Upper Egypt", Nuclear Science Journal, Vol. 38, No. 2, 141146.

[11]El-Arabi A. M, (2005)"Natural radioactivity in sand used in thermal therapy at red sea coast, Journal of Environmental Radioactivity”, 51, 11-19.

[12]El-Mageed A. I. A., Abd El-Hadi El-Kamel, Abbady A. , Harb S. , Imran I.S,(2013) "Natural radioactivity of ground and hot spring water in some areas inYemen, Radioactive Decontamination of Water, Desalination”, Volume 321,Issue null, Pages 28-31.

[13] Moreos S. A. and Messieh S. N. (1973) "Change in the current regieme in the Suez Canal after construction of Aswan High Dam”. Nature 242, 38-39

[14] Sherief M. K., Awadallah R. M. and Grass F. (1980) "Trace elements in water samples from Lake Nubia-Lake Nasser". J. RadioanaL Chem. 60, 267-272.

[15] El-Manadely, M.S., Abdel-Bary, R.M., El-Sammany, M.S., Ahmed, T.A., 2002. "Characteristic the delta formation resulting from sediment deposition in Lake Nasser, Egypt: approach to tracing lake delta formation. Lakes Reservoirs Res. Manage”. 7, 81-86.

[16] Rao S R, Londhe V S and Pillai K C (1983) - "Low level Radioactivity Measurements Using Gamma Ray Spectrometry", Bulletin of Radiation Protection, vol. 6, No.2, pp 33 - 41.

[17] Hayumbu P, Zaman M. B, Lubaba N. C. H, Munsanje S. S, and Nuleya D, (1995), "Natural radioactivity Zambian building materials collected from Lusaka”,J. Radional. Nucl. Chem. 199, pp $229-238$

[18] Ibrahim N, (1999), "Natural activities of 238U, 232Th and 40K in building materials", J.Environ. Radiact. 43, 255-258.

[19] Krieger R,(1981), “Radioactivity of construction materials”. Betonwerk Fertigteil Techn. 47, 468

[20]Beretka J, Mathew P . J, (1985), "Natural radioactivity of Australian building materials, industrial wastes and by-products". Health Phys. 48, pp $87-95$.

[21] Krisiuk F.M,Tarasov S.I, Shamov V.P, Shalak N.I,Lisachenko E.P,and Gomelsky L.G, (1971), “A study of radioactivity in building materials”. Researth Institute of Radiation Hygiene, Leningrad.

[22] Stranden, E.,(1976)“ Some aspects on radioactivity of building materials ”, Health physics. . Vol. 8, pp $167-177$

[23]NEA-OECD (1979). -NUCLEAR ENERGY AGENCY- ORGANIZATION FOR ECONOMIC COOPERATION AND DEVELOPMENT. EXPOSURE TO RADIATION FROM NATURAL RADIOACTIVITY IN BUILDING MATERIALS. REPORT BY NEA Group of Experts, OECD, Paris.

[24] Mantazul I. C., Alam M. N. and Hazari S. K. S. (1999). Distribution of radionuclides in the river sediments and coastal soils of Chittagong, Bangladesh and evaluation of the radiation hazard. Applied Radiation and Isotopes, 51, 747-755.

[25]UNSCEAR, (2000), "Sources and effects of ionizing radiation ”, New York: United Nations. Vol.1 Annex B, P 92-93.

[26] R. Said, (1962)“The Geology of Egypt”, Elsevier, Amsterdam. 
International Journal of Biomedical Engineering and Science (IJBES), Vol. 6, No. 1, January 2019

[27] Harb S. et al.,(2008) "Proceedings of the 3rd Environmental Physics Conference", 19-23 Feb.Aswan, Egypt

[28]H. M. Diab, S. A. Nouh, A. Hamdy and S. A. EL-Fiki, (2008) "Evaluation of Natural Radioactivit in acultivated Area around a Fertilizer Factory", Journal of Nuclear and Radiation Physics, vol. 3, no. 1 , pp. 53-62.

[29]El-Reefy HI, Badran HM, Sharshar T, Hilal MA, Elnimr T (2014). Factors affecting the distribution of natural and anthropogenic radionuclides in the coastal Burullus Lake. J. Environ. Radioact 134:35-42

[30] Abeer A. El Saharty and Mahmoud A. Dar(2012 "The radiological hazards of some radionuclides in Mariout and Brullus Lakes, Egypt”J. Rad. Res. Appl. Sci., Vol. 5, No. 2).

[31]El-Tahawy, M.S., Farouk, M.A., Ibrahiem, N.M.,El-.Mongey, S.A.M.,(1994). "Natural and artificial radionuclides in the Suez Canal bottomse diments and stream water. Radiat. Phys. Chem. 44, 87-89

[32] Rafat M Amin(2013), "Radioactivity Levels in Some Sediments and Water Samples from Qarun Lake by Low-Level Gamma Spectrometry" International Journal of Science and Research (IJS (Online): 2319-7064 Index Copernicus Value : 6.14

[33]Fahmi, N.M.; El-Khatib, A.; Abd El-Salam, Y.M.; Shalaby, M.H.; El-Gally, M.M. and Naim, M.A. (2010). "Study of the environmenta limpacts of the natural radioactivity presents in beach sand and Lake Sediment samples Idku, Behara, Egypt. Tenth Radiation Physics\& Protection Conference, 27-30 November 2010, Nasr City - Cairo, Egypt. 391-402. 